\title{
Morphological and molecular evidence supporting the validity of Trialeurodes lauri and T. ricini (Hemiptera: Sternorrhyncha: Aleyrodidae)
}

\author{
Christopher MALUMPHY, M. Belen SUAREZ, Rachel GLOVER, Neil BOONHAM and Dominique W. COLLINS \\ Central Science Laboratory, Sand Hutton, York YO41 1LZ, UK; e-mail: c.malumphy@csl.gov.uk
}

Key words. Aleyrodidae, Trialeurodes lauri, T. ricini, Aleyrodidae, identification, COI gene

\begin{abstract}
The whiteflies Trialeurodes lauri and T. ricini have been found to be moving in international plant trade. The taxonomic validity and separation of these species is relevant to the plant health quarantine services of the European Union as $T$. lauri is oligophagous, nor recorded as a virus vector and present in the EU, whereas T. ricini is polyphagous, reported to be a virus vector, and absent from the EU (except for the Canary Islands). Yet doubt has been cast on the validity of the two species, with the suggestion that $T$. lauri is merely a variant of $T$. ricini. The taxonomic relationship was therefore investigated using morphological and molecular data. One morphological character traditionally used for the separation of these two species, the arrangement of the submarginal papillae, was found to be unreliable but morphological differences between the two species were found in the cephalic setal state, body outline and dorsal pigmentation. However, the differences were subtle and not always reliable. The molecular data, based on the sequence of a fragment of the COI gene, support the hypothesis that $T$. ricini and $T$. lauri are distinct valid species.
\end{abstract}

\section{INTRODUCTION}

The whitefly Trialeurodes lauri (Signoret, 1882) occurs widely in the countries bordering the Mediterranean (Mound \& Halsey, 1978; Martin et al., 2000), developing on bay laurel (Laurus nobilis Linnaeus) and Grecian strawberry tree (Arbutus andrachne Linnaeus). The castor whitefly, Trialeurodes ricini (Misra, 1924), occurs widely in the Oriental Region, Middle East, sub-Saharan Africa, Egypt and the Canary Islands (Spain) (Anon., 2001; Martin et al., 2000; Mound \& Halsey, 1978). Both species are recorded from Israel. Trialeurodes ricini is broadly polyphagous but is most commonly associated with castor bean (Ricinus communis Linnaeus) and plant species belonging to the former Leguminosae (now Caesalpiniaceae, Papilionaceae and Mimosaceae). Live larvae of both whitefly species have been intercepted on imported plant material in England by the Plant Health and Seeds Inspectorate (PHSI) of the Department for Environment, Food and Rural Affairs (Defra), indicating that they are moving in international plant trade. Trialeurodes lauri has been found on strawberry tree (Arbutus unedo Linnaeus: a new host record) foliage used to make Christmas wreaths, imported from Turkey. Trialeurodes ricini is most often intercepted on fresh foliage, e.g. Amaranthus sp., nalta jute (Corchorus olitorius Linnaeus), okra (Hibiscus esculentus Linnaeus), sweet potato [Ipomoea batatas (Linnaeus) Lamarck], and Telfairia sp. all imported from West Africa, and on curry plant (Murraya koenigii (Linnaeus) Sprengel) from India.

Whitefly taxonomy is almost entirely based on the morphology of the fourth-larval instar, commonly known as the puparium or pupa (Martin et al., 2000). Morphological separation of $T$. lauri and $T$. ricini puparia is problematical due to their similarity. Martin et al. (2000) used only two character states to separate the two species, the cephalic setae and the submarginal papillae. However, dorsal setal development has been found to vary enormously due to environmental conditions in other whitefly species, most notably Trialeurodes vaporariorum (Westwood, 1856) (Russell, 1948) and Bemisia tabaci (Gennadius, 1889) (Mound, 1963, 1965; Azab et al., 1970; Harakly, 1974; David \& Ananthakrishnan, 1976; Mohanty \& Basu, 1986; Bethke et al., 1991). Neal \& Bentz (1999) demonstrated that the phenotypic plasticity of dorsal structures in $T$. vaporariorum was determined by the tactile experience of the first-larval instar, which is related to leaf topography, plant species, population density and other factors. Martin et al. (2000) therefore suggested that $T$. lauri might prove to be a variant or "smooth-leaf" form of $T$. ricini.

The taxonomic status of these two species, and their recognition, has particular relevance to the plant health quarantine services within the European Union (EU) as $T$. lauri is present in the Member States bordering the Mediterranean and is not a virus vector, whereas T. ricini is absent (with the exception of the Canary Islands) and reported to be a virus vector. Trialeurodes ricini is a polyphagous, multivoltine species, which is difficult to control and is a serious pest of tomatoes (Idriss et al., 1997). In Egypt, T. ricini has been reported as a vector of the begomovirus Tomato yellow leaf curl virus (TYLCV) (Idriss et al., 1997) although other researchers have as yet been unable to duplicate these findings (Jones, 2003). TYLCV is listed in the plant health legislation of the EU (Smith et al., 1997).

The purpose of this communication is therefore to clarify the taxonomic relationship between $T$. lauri and $T$. ricini, and to determine an accurate means for their separation. In order to complement morphological investiga- 
tion, sequence comparisons from a fragment of the cytochrome oxidase subunit I (COI) from the mitochondrial genome were also carried out, to determine whether if support could be gained for the discrimination of the two groups into distinct species.

\section{MATERIAL AND METHODS}

\section{Study material and specimen depository}

Study material was collected by the PHSI on imported plant material during phytosanitary inspections in England and Wales, and by field collecting in Croatia, the Canary Islands and Egypt. Material was also obtained from Prof. Dan Gerling of the Tel Aviv University, Israel, and from cultures reared at the Central Science Laboratory (CSL) under licence. Detailed morphological descriptions and/or illustrations of T. lauri puparia have been published by Bink-Moenen \& Gerling (1990) and Martin et al. (2000); and of T. ricini by Bink-Moenen (1983) and Martin et al. (2000). As a starting point, specimens were initially segregated into putative $T$. lauri and T. ricini on the basis of host and the key provided by Martin et al. (2000). In total, 20 T. lauri puparia were collected from three host plants from three countries, and $52 T$. ricini puparia were collected from six host plants from seven countries. Only morphological differences noted during the present study are recorded here.

\section{Collection details}

\section{Trialeurodes lauri (Signoret)}

CROATIA: Cavtat, on L. nobilis, 8.x.2004, Jon Martin, (2 puparia). ISRAEL: Tel Aviv University, on A. andrachne, 27.ix.2004, Dan Gerling, CSL-20416157 (4 puparia). TURKEY: (intercepted in UK), on $A$. unedo, 1.xii.2000, PHSI, CSL2029265 (8 puparia), 14.xii.2000, CSL-2029631 (6 puparia).

\section{Trialeurodes ricini (Misra)}

CAMEROON: (intercepted in UK), on unidentified leaves, 27.viii.1997, PHSI CSL-975665 (2 puparia). EGYPT: on $R$. communis, 2.x.2003, J. Elphinstone (3 puparia). GAMBIA: (intercepted in UK), on unidentified leaves, 14.x.2003, PHSI, CSL-20314148 (1 puparium). GHANA: (intercepted in UK), on H. esculentus, 7.ii.2001, PHSI, CSL-2010475 (1 puparium); on unidentified leaves, 6.vii.2005, PHSI, CSL-20511104 (3 puparia). INDIA: (intercepted in UK), on $M$. koenigii, 29.ix.2004, PHSI, CSL-20416604 (3 puparia). NIGERIA: (intercepted in UK), on Amaranthus sp., 10.xii.1998, PHSI, CSL987234 (1 puparium); on Telfaria sp., 26.ii.2002, PHSI, CSL2020953 (15 puparia); on unidentified leaves, 30.v.2001, PHSI, CSL-2012363 (2 parasitized puparia); 28.iii.2002, PHSI, CSL2021569 (3 puparia); 21.i.2004, PHSI, CSL-20400432 (1 puparium). CANARY ISLANDS (SPAIN): Gran Canaria, Margazan, on $R$. communis, 9.i.2003, C. Malumphy (15 puparia). Cultured under licence at the CSL, Phaseolus vulgaris Linnaeus, 6.iii.2003, (2 puparia).

Slide-mounted specimens have been deposited in the reference collections at CSL.

\section{Morphological examination}

Specimens were slide-mounted according to the protocol provided by Malumphy (2004). Canada balsam was employed as the mountant for permanent preparations of puparia and Heinz for early-larval instars. Specimens were examined under Leitz Diaplan and Zeiss Universal Compound Research microscopes with phase and interference contrast using magnifications up to $\times 1250$. Fresh specimens were also studied with a Philips XL20 Scanning Electron Microscope after sputter-coating them with gold in an Emscope SC500. Morphological terminology used here follows Martin et al. (2000).

\section{DNA extraction}

Each DNA extraction was carried out from a single insect according to the Chelex 100 (BioRad) method described by Walsh et al. (1991). An electric mixer was used for homogenisation of the starting material. The purified DNA was resuspended in $50 \mu \mathrm{L}$ of nuclease free water and stored at $-20^{\circ} \mathrm{C}$ until use.

\section{Amplification and sequencing of COI gene fragment}

A mitochondrial cytochrome oxidase subunit I (COI) gene fragment was amplified by PCR using the primers 5'TTGATTTTTTGGTCATCCAGAAGT-3' and 5'TCCAATGCACTAATCTGCCATATTA-3' (Frohlich et al., 1999). All reaction volumes were $50 \mu 1$, containing $0.2 \mu \mathrm{M}$ each primer, $0.2 \mathrm{mM}$ dNTPs, $2.5 \mathrm{mM} \mathrm{MgCl} 2,2 \mu \mathrm{L}$ whitefly DNA, $1 \mathrm{X}$ supplied buffer and $2 \mathrm{U}$ BIO-X-ACT Long DNA polymerase (Bioline). PCR conditions were 2 min at $94^{\circ} \mathrm{C}, 40$ cycles at $94^{\circ} \mathrm{C}$ for $1 \mathrm{~min}, 50^{\circ} \mathrm{C}$ for $1 \mathrm{~min}$ and $72^{\circ} \mathrm{C}$ for $1 \mathrm{~min}$, and a final cycle at $72^{\circ} \mathrm{C}$ for $10 \mathrm{~min}$. After agarose gel electrophoresis, the resulting PCR products (approximately $850 \mathrm{bp}$ ) were excised and purified using the MiniElute Gel Extraction Kit (Qiagen) according to the manufacturer's protocol. Eluted PCR products (200 ng approximately) were sent to Sequiserve (Vaterstetten, Germany) for sequencing in both directions using the amplification primers. The sequences obtained for each individual were assembled and manually edited using the SeqMan program from the DNASTAR package (Lasergene).

\section{Sequence analysis}

A region of sequence amplified for all species (T. lauri, $B$. tabaci, $T$. ricini $=641 \mathrm{nt} ;$ T . vaporariorum $=638 \mathrm{nt}$ ) was aligned using the Clustal V method described by Higgins and Sharp (1989) within the program MegAlign (DNASTAR, Lasergene). Cluster analysis was carried out using the program PAUP*4.0b10 (Swofford et al., 2000). A distance tree was produced using the neighbour-joining (NJ) algorithm based on the Tajima-Nei distance matrix with 1000 bootstrap replications. To examine the reliability of the tree produced by the NJ method, we also constructed a Maximum Likelihood (ML) tree, again with 1000 bootstrap replications. Heuristic searches (rather than exact searches) were performed due to lack of computational resources.

\section{RESULTS}

\section{Body outline}

The outline of the T. lauri puparia was oval with no indentation at the spiracular pores (Fig. 1). The outline of the $T$. ricini puparia was also oval or lozenge but there was a slight indentation at the spiracular pores and the margin was more irregular (Figs 2 and 3). Puparia of $T$. ricini collected from hirsute leaves often had the margin distorted by the plant hairs, whereas the foliage of the host plants of $T$. lauri was glabrous.

\section{Dorsal setae}

Cephalic setae, when present, are a pair of setae located on the dorsal surface of the head (Fig. 3). They were absent in all the T. lauri specimens examined (Figs 1 and 5 ), whereas they were always present and relatively conspicuous in the $T$. ricini specimens (Figs 2, 3, 4, 6, 7). The setae were fine, pointed, usually curved, length 17.7 $\pm 3.5 \mu \mathrm{m}(14-24 \mu \mathrm{m}, \mathrm{n}=23)$, with large bases, 4-6 $\mu \mathrm{m}$ wide. The first abdominal and eighth abdominal setae were always present and well developed in both species. 

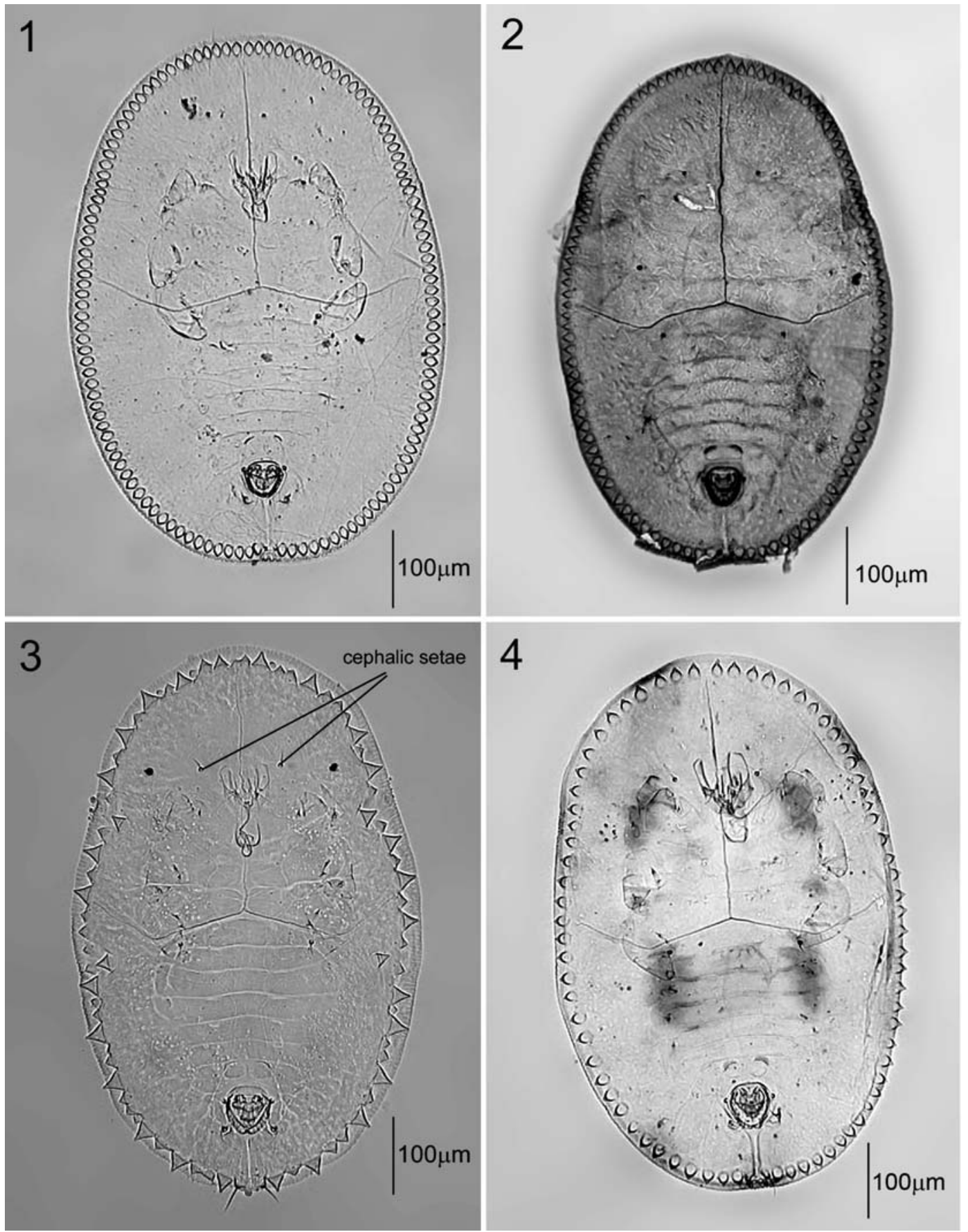

Figs 1-4. 1 - Trialeurodes lauri puparium (Arbutus enudo ex Turkey); 2 - Trialeurodes ricini puparium (Telfairia ex Nigeria); 3 Trialeurodes ricini puparium (Ricinus communis ex Gran Canaria, Spain); 4 - Trialeurodes ricini puparium (Hibiscus ex Ghana).

\section{Dorsal papillae}

The submarginal papillae were always small, uniform in size, almost contiguous and in a single row in all specimens of T. lauri (Fig. 1). Papillae were always absent from the subdorsal region. The size, number and position of the submarginal and subdorsal papillae in the specimens of $T$. ricini were highly variable, even among specimens collected from the same leaf. The submarginal tubercle arrangement was either almost identical to $T$. lauri (Fig. 2), or highly irregular in size and position (Fig. 3 ). Subdorsal papillae only occurred in specimens with highly irregular submarginal papillae. The sample size was too small to link the variation observed in $T$. ricini with host or origin.

Long translucent wax rods are extruded from the submarginal papillae and were always horizontal and densely packed in T. lauri (Fig. 5), whereas they were either solely horizontal, a mixture of horizontal and erect, or mostly erect in $T$. ricini (Fig. 6). This variation was observed among individuals collected from the same population; for example, T. ricini puparia collected from a single $R$. communis plant in Gran Canaria exhibited the full range of variation observed. 

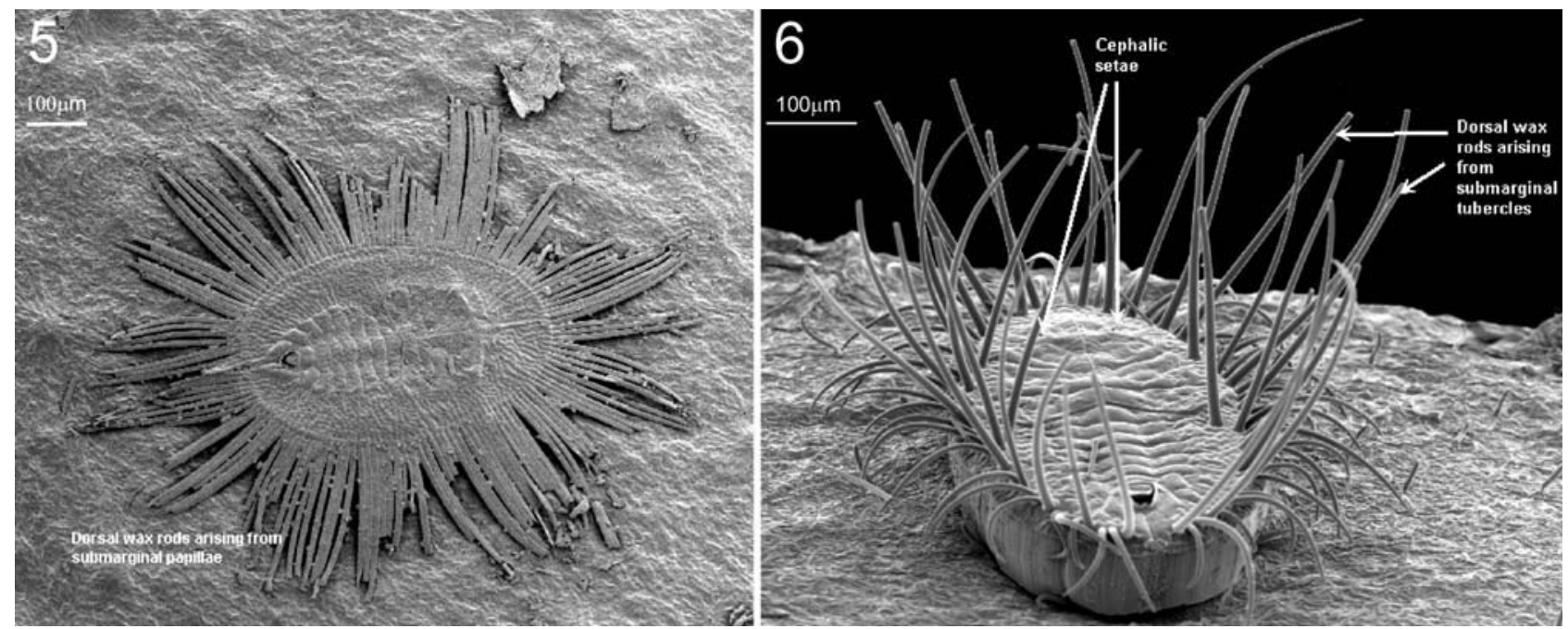

Figs 5, 6. 5 - scanning electron micrograph of Trialeurodes lauri puparium (Arbutus enudo ex Turkey), showing the horizontal dorsal wax rods; 6 - scanning electron micrograph of Trialeurodes ricini puparium (Ricinus communis ex Gran Canaria, Spain), showing cephalic setae and erect dorsal wax rods.

\section{Dorsal pigmentation}

Dorsal pigmentation was absent in T. lauri; whereas up to three pairs of dark-brown patches were observed in $T$. ricini (Fig. 4). The patches often coalesced to form two longitudinal subdorsal steaks. This character was highly variable and was present or absent in specimens collected from the same leaf. In several of the populations, for example from Gran Canaria and Nigeria, pigmentation was present in the majority of the puparia.

\section{Sequence analysis}

The results (Figs $8 \mathrm{a}$ and $8 \mathrm{~b}$ ) show that the sequences for T. ricini and T. lauri fall into two distinct clusters supported by high bootstrap values $(100 \%)$. The sequences within the clusters share a high percentage of sequence identity (92.5-100\% and 98.6-100\% respectively) but much lower identity between clusters $(80.4-81.2 \%)$.

\section{DISCUSSION}

The initial segregation of the study material made here into putative $T$. lauri and $T$. ricini was validated by both morphological and molecular investigation, strongly supporting the hypothesis that these are two distinct, separate

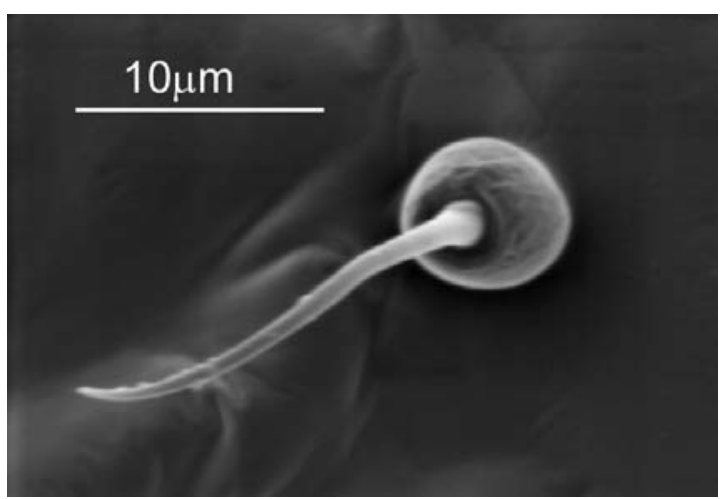

Fig. 7. Scanning electron micrograph of the cephalic seta of Trialeurodes ricini. species. Segregation of the two species based on the absence or presence of the cephalic setae (Martin et al., 2000) was clearly supported by the molecular data based on the sequence of a fragment of the COI gene for both the putative $T$. ricini and $T$. lauri. The sequences from the two morphological segregates form tight and distinct clusters. In addition, sequence from another species, $T$. vaporariorum, was also included in the analysis; sequence from individuals from this species also clustered very tightly. There are a number of factors that make study of the sequence from the COI mitochondrial genome appropriate for this kind of work. Firstly, conserved regions of sequence mean that fragments can be amplified using PCR with universal primer sets (Frohlich et al., 1999); secondly, the mitochondrial genome does not contain introns and has little recombination due to its haploid inheritance (Saccone et al., 1999); finally, the coding regions do not contain insertions or deletions (indels) which would cause frame shift mutations in the genes and difficulty with subsequent analysis (Doyle \& Gaut, 2000). The sequence of COI has been used by a number of researchers for the identification of species and in particular for the discrimination of closely related invertebrate species (Brunner et al., 2002; Hebert et al., 2003; Foster et al., 2004).

This result accords with the known biological differences between the species. The broadly polyphagous $T$. ricini is multivoltine, whereas the univoltine $T$. lauri appears to be restricted to Arbutus (Ericaceae) and Laurus (Lauraceae). Gerling (2004) showed that T. lauri has an unusual and slightly complex biology on its main host in Israel, the Grecian strawberry tree. There, it is closely synchronized with the annual cycle of its evergreen host. In the laboratory, $T$. ricini from the population collected from Ricinus communis in Gran Canaria readily colonised Phaseolus vulgaris and Momordica charantia Linnaeus plants in culture at the CSL but would not lay eggs 

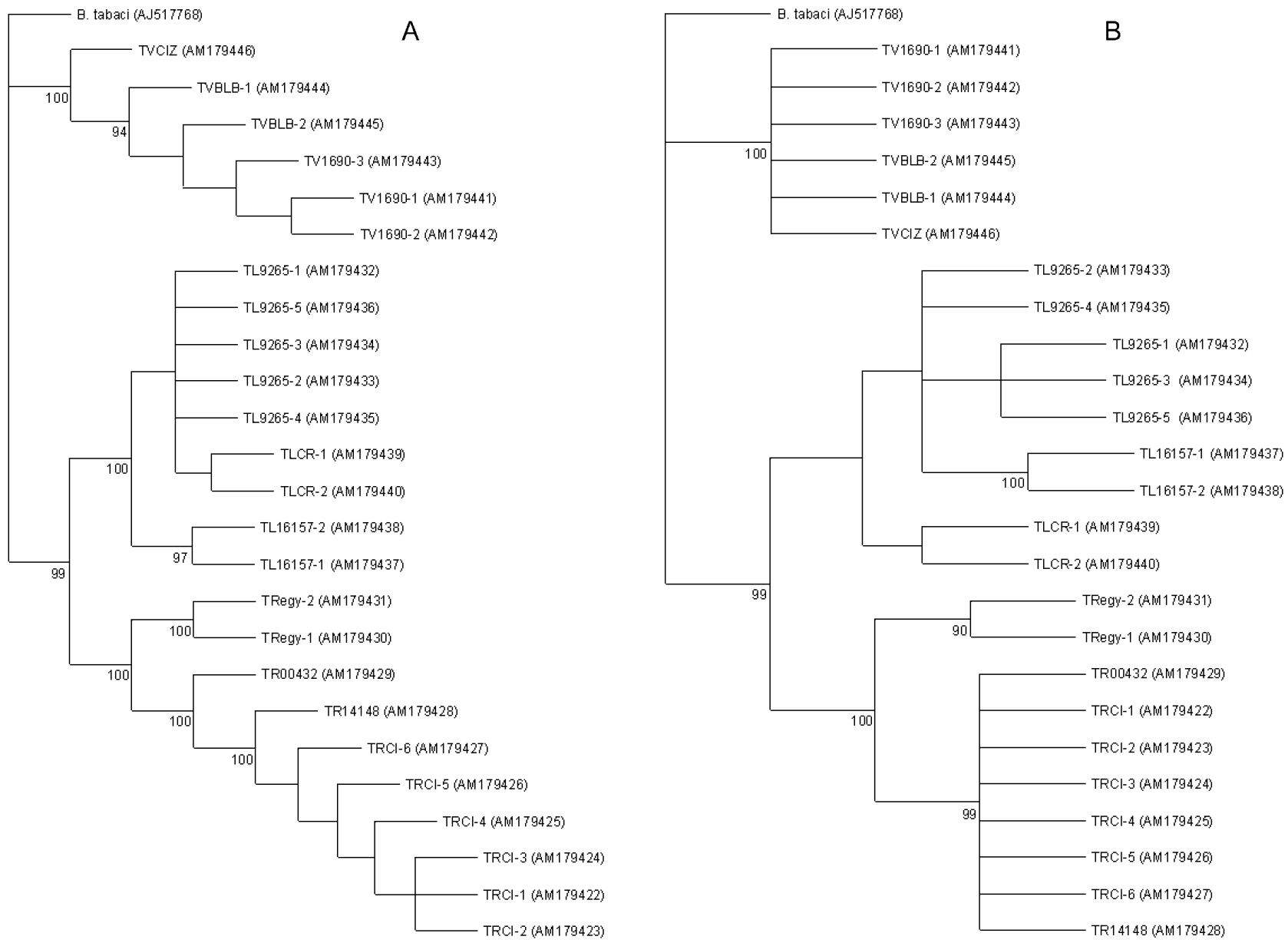

Fig. 8. Rooted trees illustrating the relatedness of COI sequences from three species of Trialeurodes (T. ricini, T. lauri, T. vaporariorum); the COI sequence from $B$. tabaci was used as the outgroup sequence in each case. (A) was obtained by the distance method using the Tajima-Nei model, whilst (B) was obtained using the maximum likelihood method. The numbers below the branches indicate the percentage ( $>90 \%$ ) of the number of times the branch point to the right was recovered following 1000 bootstrap re-samplings of the original data. T. ricini, TRCI - Ricinus communis, ex Canary Islands; TR14148 - unidentified leaves, ex Gambia; TR00432 - unidentified leaves, ex Nigeria; TRegy - R. communis, ex Egypt. T. lauri, TL16157 - Arbutus andrachne, Israel; TLCR - Laurus nobilis, Croatia; TL9265 - A. unedo, ex Turkey. T. vaporariorum, TVCIZ - unidentified leaves, ex Canary Islands; TVBLB - Primula sp., England; TV1690 - Gerbera sp., ex the Netherlands.

on Laurus nobilis when kept under identical environmental conditions.

The state of the cephalic setae, when visible, was found to be the most reliable morphological character for separating $T$. lauri from $T$. ricini, when examining the relatively small number of specimens available during this study. The cephalic setal pair was absent in T. lauri and relatively conspicuous (more than $14 \mu \mathrm{m}$ ) in $T$. ricini. Bink-Moenen \& Gerling (1990), however, observed some specimens of $T$. lauri with minute cephalic setae; they illustrate the setae as subequal in length to the width of the setal bases. In addition, it is often very difficult to physically remove or dissolve the thick dorsal layer of wax on T. lauri puparia and, to a lesser degree, T. ricini puparia, using standard slide-mounting protocols (Martin, 1987; Malumphy, 2004). If the dorsal layer wax is inadequately removed it can be difficult or impossible to see the cephalic setae. Even when the wax layer is removed, there is also a risk of detaching the setae and the presence of setal bases could indicate either species. Bink-Moenen
\& Gerling (1990) did not record the size of the setal bases but it is unlikely that there would be a diagnostic difference between the sizes of the setal bases of the two species. Although cephalic setal state was found to be a reliable diagnostic character in good slide mountedspecimens, quarantine diagnostic services often have to identify very small numbers of specimens in poor condition and using this single character is not always practical.

The second morphological character used by Martin et al. (2000) to separate these species was the arrangement of the submarginal papillae. This character was here found to be completely unreliable. The submarginal tubercle arrangement in $T$. ricini is highly plastic, even among specimens from the same population. For example, specimens of $T$. ricini intercepted in England on imported Nigerian Amaranthus leaves have irregular submarginal papillae, or papillae in a single, regular, almost contiguous row. David \& Ananthakrishnan (1976) previously reported host-induced phenotypic variation in $T$. 
ricini (under the name of T. rara Singh, 1931) and BinkMoenen (1983) noted three main morphological forms, which she associated with different host plants. These were, the "ricini form" with small, uniform, contiguous submarginal papillae in a single regular row, collected from the plant genera Bombax, Dalbergia, Gargenia, Gossypium, Hymenocardia, Mitragyna and Sida; the "rara form" with enlarged papillae separated by between two to four smaller papillae in a non-contiguous, slightly irregular, single row, collected from Aspilia, Gossypium and Hexalobus; and the "desmodii form" with almost all the papillae enlarged in an irregular, partially double row, collected from Cordia and Crossopteryx. However, these forms were not distinct and Bink-Moenen also recorded intermediates, and found the "ricini" and "rara" forms on Gossypium.

Two hitherto unrecorded morphological differences between $T$. lauri and $T$. ricini are the body outline and the presence or absence of dorsal pigmentation. The difference in body outline between the species is subtle and difficult to judge without having numerous specimens with which to compare. The presence or absence of pigmentation was found to be a good character and was present in the majority of the $T$. ricini puparia examined from Gran Canaria and Nigeria. It appears surprising that this has not been observed before but pigmentation may prove unreliable when more specimens are examined. It may also be lost if specimens are macerated for too long or masked by staining during the slide mounting process. Variation in dorsal pigmentation has been reported in other whitefly species, for example, Aleurothrixus floccosus (Maskell, 1895) (Malumphy, 1995).

The morphological differences between the puparia of $T$. lauri and $T$. ricini are subtle and there could still remain some uncertainty as to their morphological separation given that the character found to be most reliable here, cephalic setal state, exhibits enormous phenotypic plasticity in other species of Trialeurodes.

ACKNOWLEDGEMENTS. We thank J. Martin (BMNH, London), D. Gerling (Tel Aviv University, Ramat Aviv, Israel), J. Elphinstone (CSL) and the Plant Health and Seeds Inspectorate for supplying us with study material. This work was funded by Plant Health Division, Department for Environment, Food and Rural Affairs, UK. Whitefly cultures were maintained under the authority of Licence No. PHL 251/4422(03/2003).

\section{REFERENCES}

Anonymous 2001: Crop Protection Compendium, Global Module. 3rd ed. CAB International, CD-Rom Database.

Azab A.K., Megahed M.M. \& El-Mirsawi H.D. 1970: Effect of degree of pubescence of host-plant on the number and distribution of dorsal spines in pupa of Bemisia tabaci (Genn.) (Hemiptera-Homoptera: Aleyrodidae). Bull. Soc. Entomol. Egypte 53[1969]: 353-357.

BethKe J.A., Paine T.D. \& Nuessly G.S. 1991: Comparative biology, morphometrics, and development of two populations of Bemisia tabaci (Homoptera: Aleyrodidae) on cotton and poinsettia. Ann. Entomol. Soc. Am. 84: 407-411.

BinK-Moenen R.M. 1983: Revision of the African whiteflies (Aleyrodidae). Monografieëvan de Nederlandse Entomologische Vereniging. No. 10.210 pp.
Bink-Moenen R.M. \& Gerling D. 1990: Aleyrodidae of Israel. Boll. Lab. Entomol. Agr. Filippo Silvestri 47: 3-49.

Brunner P.C., Fleming C. \& Frey J.E. 2002: A molecular identification key for economically important thrips species (Thysanoptera: Thripidae) using direct sequencing and a PCRRFLP-based approach. Agric. Forest Entomol. 4: 127-136.

DAVID B.V. \& ANANThaKRishnan T.N. 1976: Host correlated variation in Trialeurodes rara Singh and Bemisia tabaci (Gennadius) (Aleyrodidae: Homoptera: Insecta). Curr. Sci. 45: 223-225.

Doyle J.J. \& Gaut B.S. 2000: Evolution of genes and taxa: a primer. Plant Mol. Biol. 42: 1-23.

Foster B.T., Cognato A.I. \& Gold R.E. 2004: DNA-based identification of the eastern subterranean termite, Reticulitermes flavipes (Isoptera: Rhinotermitidae). J. Econ. Entomol. 97: 95-101.

Frohlich D.R., Torres-Jerez I., Bedford I.D., Markham P.G. \& BROwN J.K. 1999: A phylogeographical analysis of Bemisia tabaci species complex based on mitochondrial DNA markers. Mol. Ecol. 8: 1683-1691.

GerLing D. 2004: The unique annual cycle of the whitefly Trialeurodes lauri on the strawberry tree (Arbutus andrachne). 2nd European Whitefly Symposium Abstract Compendium. (EWSII), 5-9 October 2004, Cavtat, Croatia. Institute for Adriatic Crops and Karst Reclamation, p. 13.

HARAKLY F.A. 1974: Variation in pupae of Bemisia tabaci (Gennadius) bred on different hosts (Homoptera: Aleyrodidae). Bull. Soc. Entomol. Egypte 57[1973]: 407-412.

Herbert P.D.N., Cywinska A., Ball S.L. \& DeWaard J.R. 2003: Biological identifications through DNA barcodes. Proc. R. Soc. Lond. (B) 270: 313-321.

Higgins D.G. \& Sharp P.M. 1989: Fast and sensitive multiple sequence alignments on a microcomputer. CABIOS 5: $151-153$.

Idriss M., Abdallah N., Aref N., Haridy G. \& Madkour M.A. 1997: Biotypes of the castor bean whitefly Trialeurodes ricini (Misra) (Hom., Aleyrodidae) in Egypt: Biochemical characterization and efficiency of geminivirus transmission. J. Appl. Entomol. 121: 501-509.

JONES D.R. 2003: Plant viruses transmitted by whiteflies. Eur. J. Plant Pathol. 109: 195-219.

Malumphy C. 1995: Woolly whitefly, Aleurothrixus floccosus (Maskell), a pest of ornamental Citrus new to Britain (Homoptera: Aleyrodidae) Entomol. Gaz. 46: 217-220.

Malumphy C. 2004: Diagnostic protocols for regulated pests Bemisia tabaci. OEPP/EPPO Bull. 34: 281-288.

MARTIN J.H. 1987: An identification guide to common whitefly pest species of the world (Homoptera, Aleyrodidae). Trop. Pest Manag. 33: 298-322.

Martin J.H., Mifsud D. \& Rapisarda C. 2000: The whiteflies (Hemiptera: Aleyrodidae) of Europe and the Mediterranean Basin. Bull. Entomol. Res. 90: 407-448.

Mohanty A.K. \& Basu A.N. 1986: Effect of host plants and seasonal factors on intraspecific variations in pupal morphology of the whitefly vector, Bemisia tabaci (Genn.) (Homoptera: Aleyrodidae). J. Entomol. Res. 10: 19-26.

Mound L.A. 1963: Host-correlated variation in Bemisia tabaci (Gennadius) (Homoptera: Aleyrodidae). Proc. R. Entomol. Soc. London (A) 38: 171-180.

Mound L.A. 1965: An introduction to the Aleyrodidae of Western Africa (Homoptera). Bull. Br. Mus. (Nat. Hist.) Entomol. 17: 115-160.

Mound L.A. \& Halsey S.H. 1978: Whitefly of the World. A Systematic Catalogue of the Aleyrodidae (Homoptera) with Host 
Plant and Natural Enemy Data. British Museum (Natural History) / John Wiley \& Sons, Chichester, 340 pp.

Neal J.W. \& Bentz J. 1999: Evidence for the stage inducing phenotypic plasticity in pupae of the polyphagous whiteflies Trialeurodes vaporariorum and Bemisia argentifolii (Homoptera: Aleyrodidae) and the raison d'être. Ann. Entomol. Soc. Am. 92: 754-787.

Russell L.M. 1948: The North American species of whiteflies of the genus Trialeurodes. Misc. Publ. U.S. Dep. Agric. 635: $1-85$.

Saccone C., De Giorgi C., Gissi C., Pesole G. \& Reyes A. 1999: Evolutionary genomics in Metazoa: the mitochondrial DNA as a model system. Gene 238: 195-209.
Smith I.M., McNamara D.G., Scott P.R. \& Holderness M. (eds) 1997: Quarantine Pests for Europe. 2nd ed. CABI / EPPO, Wallingford, $1432 \mathrm{pp}$.

Swofford D.L. 2000: PAUP*: Phylogenetic Analysis Using Parsimony (*and Other Methods). Version 4. Sinauer Associates, Massachusetts.

Walsh P.S., Metzger D.A. \& Higuchi R. 1991: Chelex 100 as a medium for simple extraction of DNA for PCR-based typing from forensic material. Biotechniques 10: 506-513.

Received March 30, 2006; revised and accepted February 6, 2007 